\title{
Ön Lisans İş Sağlığı ve Güvenliği Eğitiminin Mevcut Durumunun Analizine Yönelik Bir Araştırma
}

\author{
A Study on the Analysis of the Current Situation of Associate Degree Occupational Health and Safety \\ Education
}

Hasan TUNA ${ }^{1}$, Hikmet KARAÇAM ${ }^{2}$

\section{ÖZ}

İş sağlığı ve güvenliği çok disiplinli (mühendislik, kimya, fizik, hukuk, tıp vb.) bir bilim dalıdır. İş sağlığı ve güvenliği alanında farklı görevlerde ve farklı bilgi, beceri, yetenek düzeylerinde çalışacak nitelikli eleman eksikliği bulunmaktadır. Bu ihtiyacın büyüklüğünden kaynaklı birçok vakıf ve devlet üniversitesinde iş sağlığı ve güvenliği ön lisans programları açılmıştır. Ön lisans program sayısındaki bu artış bazı sıkıntıları da beraberinde getirmiştir.

$\mathrm{Bu}$ araştırmada, Türkiye'deki ön lisans iş sağlığ ve güvenliği programları incelenerek çeşitlilik gösteren programlar arasında bir birlikteliğin var olup olmadığı ve ön lisans eğitiminin mevcut durumunun belirlenmesi amaçlanmıştır. Bu amaçla Türkiye'deki 78 iş sağlıği ve güvenliği ön lisans programının ders planı ve ders içeriği, internet verilerine dayanılarak incelenmiştir.

İş sağlığı ve güvenliği ön lisans programları değerlendirildiğinde standart bir uygulama bulunmadığı saptanmıştır. Araştırmada farklı ders adlar1, farkl1 krediler ve farkl1 dönemlerde okutulan derslerle karşılaşılmıştır. Programlar arası bir birliktelik değil dağınıklık ve kopukluk olduğu tespit edilmiştir. Araştırma sonucunda, ön lisans iş sağlığ1 ve güvenliği eğitiminde bir standart olması gerekliliği ortaya çıkmıştır.

Anahtar Kelimeler: Ders Programı, İş Sağlığı ve Güvenliği, Ön Lisans Programı

\begin{abstract}
Occupational health and safety is a multidisciplinary (engineering, chemistry, physics, law, medicine, etc.) discipline. In the field of occupational health and safety, there is a shortage of qualified personnel to work in different roles and at different levels of knowledge, skills and abilities. Occupational health and safety associate degree programs have been opened in many foundation and state universities due to the magnitude of this need. This increase in the number of associate degree programs has brought some problems.
\end{abstract}

In this research, it is aimed to determine whether there is a co-existence between the various programs and the current status of the associate degree education by examining the associate degree occupational health and safety programs in Turkey. For this purpose, the lesson plan and course content of 78 occupational health and safety associate degree programs in Turkey were examined based on internet data.

When occupational health and safety associate degree programs were evaluated, it was determined that there was no standard practice. In the research, different course names, different credits and courses taught in different periods were encountered. It has been determined that there is not a unity between the programs, but a disorganization and disconnection. As a result of this research, it has emerged that there should be a standard in associate degree occupational health and safety education.

Keywords: Syllabus, Occupational Health and Safety, Associate Degree Program

\footnotetext{
Bu çalışma birinci yazarın doktora tezinden üretilmiş olup 6. Uluslararası İş Sağlı̆̆ı ve Çalışan Sağlı̆ğ Kongresinde özet bildiri olarak sunulmuştur

1 Öğr. Gör. Dr., Hasan TUNA, İş Sağlığı ve Güvenliği, Gümüşhane Üniversitesi Elektrik ve Enerji Bölümü, hasan.tuna@gumushane.edu.tr, ORCID: 0000-0003-3194-7216

${ }^{2}$ Prof. Dr., Hikmet KARAÇAM, Gıda Mühendisliği, Avrasya Üniversitesi Gıda Mühendisliği Bölümü, hikmet.karacam@avrasya.edu.tr, ORCID: 0000-0002-1899-2373
} 


\section{GíRiş}

İş sağlığı ve güvenliği (İSG) alanındaki çalışmalara bakıldığında Roma ve Antik Yunan dönemine kadar uzanan derin bir geçmişe sahiptir. 17. yüzyılda Bernardino Ramazzini'nin bulgu ve tecrübeleriyle kaleme aldığ 1 "De Morbis Artificum Diatriba" meslek hastalıkları kitabı ISG alanında yayınlanmış ilk bilimsel çalışmadır. ${ }^{1}$ İSG ile ilgili faaliyetler Sanayi Devrimi ile birlikte hız kazanmıştır.

Çalışan bireylerin güvensiz ve sağlıksız çalışma ortamları, çalışma sürelerinin çok uzun olması, çalışma ücretlerinin düşük olması gibi çalışma hayatını olumsuz etkileyen değişikliklerin önlenmesi için yasal düzenlemeler yapılmıştır. İngiltere'de 1802 yılında "Çırakların Sağlığı ve Morali" isimli yasa, 1833 y1lında ise "Fabrikalar Yasası" yürürlüğe girmiştir. ${ }^{1}$ Uluslararası Çalışma Örgütü'nün kurulması ISSG alanında yapılmış olan çalışma boyutunun uluslararası alana taşınmasına büyük katkı sağlamıştır. ${ }^{2}$ ISG alanında yapılmış olan yasalar ilk başlarda kadın ve çocukların korunmasına yönelik şekilde düzenlemeler içerirken, II. Dünya Savaşı'ndan sonra siyasi ve iktisadi koşullardaki değişimler İSG'yi bir anabilim dalı haline getirmiștir. ${ }^{3}$

İş kazaları ve meslek hastalıklarının iş hayatında çok ciddi bir boyutta problem olarak gündeme gelmesi, dünyada olduğu gibi Türkiye'de de İSG kavramının öne çıkmasında öncülük etmiştir. ${ }^{4}$ Türkiye'de, İSG'ye verilen önem her geçen gün artmaktadır. Son yıllarda çıkarılan kanun ve yönetmeliklerle İSG alanında önemli adımlar atılmasına rağmen Türkiye iş kazaları açısından Avrupa'da birinci, dünyada ise üçüncü sıradadır. ${ }^{5}$

Çalışma ve Sosyal Güvenlik Bakanlığı (ÇSGB) iş güvenliği müfettişlerinin yaptıkları denetimlerde işyerlerinin \%82,92'sinde en büyük eksikliğin işveren ve çalışanların eğitimsizliği olduğu tespit edilmiştir. Oysaki Uluslararası Çalışma Örgütü'ne göre \%98 oranında insan hatasından kaynaklanan iş kazalarının, İSG eğitimleri ile önlenmesinin mümkün olabileceği saptanmıştır. ${ }^{6}$ Türkiye'deki iş kazalarını ve meslek hastalıklarını önlemek için ülke genelinde iş sağlığı ve güvenliği kültürünün yaygınlaştırılması büyük önem arz etmektedir. ISG kültürünün oluşturulmasında eğitimin çok önemli bir rolü vardır. ${ }^{7}$ ISSG eğitimlerinin amacı, İSG bilincinin oluşturulması, çalışanın karşılaşabileceği mesleki riskler ve alınması gerekli tedbirlerin öğretilmesidir. ${ }^{8}$ ISG eğitimlerinin örgün eğitim programlarına ilköğretimden itibaren konulması ve yükseköğretimde ilgili tüm okullarda ders programına girmesi İSG kültürünü oluşturulmasında önemli rol oynayabilir. Türkiye'deki yükseköğretimde ön lisans, lisans ve lisansüstü düzeyinde İSG eğitimi verilmektedir.

Türkiye'de en yaygın İSG eğitimi ön lisans düzeyinde verilmektedir. Mezun olan ön lisans İSG öğrencileri "İ̧s Sağlığı ve Güvenliği Teknikeri” unvanı almaktadır. Ayrıca 6331 sayılı İş Sağlığı ve Güvenliği Kanunu'nun 3. maddesine göre üniversitelerin ISG ön lisans programlarından mezun olanlar iş güvenliği uzmanı da olabilmektedir. ${ }^{9}$ ISG ön lisans mezunları 220 saatlik bir eğitim aldıktan sonra sınavda başarılı olurlarsa C sınıfı iş güvenliği uzmanı olarak kariyerlerine başlayabilir. ${ }^{10}$

İSG teknikeri yetiştiren ilk ön lisans programı 1996 yılında açılmıştır. ${ }^{11} 2005$ yılına kadar Meslek Yüksekokulları (MYO) bünyesinde iki İSG programı olduğu tespit edilmiștir. $^{12}$ Hem devlet hem de vakıf üniversitelerinin MYO'ları bünyesinde oluşturulan ISG programlarının sayısı her geçen gün artmaktadır. 2011 yılında ön lisans düzeyinde ISG eğitimi veren toplam üniversite sayıs1 15 iken, 2012 yılında bu sayı 25'e yükselmiştir. 2012 y1lında 25 üniversitenin 36 farklı programında (normal, ikinci, uzaktan öğretim) İSG eğitimi verilirken $^{11}, 2015$ yılında 52 üniversitenin 94 farklı programinda (normal, ikinci, uzaktan ve açık öğretim) ${ }^{13}$ ve 2018 yılında toplam 77 
üniversitenin 137 farklı programında (normal, ikinci, uzaktan ve açık öğretim) ${ }^{5}$ İSG eğitimi verildiği tespit edilmiştir. 2019 yılında ise toplam 84 üniversitenin 145 farklı programında (normal, ikinci, uzaktan ve açık öğretim) İSG eğitimi verilmektedir. ${ }^{14}$

İSG ön lisans programlarına yeni kayıt yaptıran ve programlarda okuyan öğrenci sayıları gün geçtikçe artmaktadır. Mevcut okuyan İSG ön lisans öğrenci sayıları 20132014 Eğitim Öğretim Y1lı'nda 13.136 iken, 2019-2020 Eğitim Öğretim Yılı'nda bu say1 109.188'e ulaşmıştır. 2013-2014 Eğitim Öğretim Y1lı ile 2019-2020 Eğitim Öğretim Yılı'na ait veriler karşılaştırıldığında yeni kayıt sayısında 2,52 mevcut okuyan öğrenci sayısında ise 7,31 kat artmıştır. Ön lisans programlarından mezun olan öğrenci sayıları da gün geçtikçe artmaktadır. Mezun olan İSG ön lisans öğrenci sayıları 2012-2013 Eğitim Öğretim Yilı'nda 587 iken, 2018-2019 Eğitim Öğretim Yılı'nda bu sayı 9.847'ye ulaşmıştır. ${ }^{15}$

İSG alanında farklı görevlerde (A,B,C iş güvenliği uzmanı ve İSG teknikeri) ve farklı bilgi, beceri, yetenek düzeylerinde çalışacak nitelikli eleman eksikliği bulunmaktadır.
2012 y1lında 6331 sayılı İş Sağlığ 1 ve Güvenliği Kanununun çıkartılmasıyla birlikte bu alanda çalışabilecek uzman ve tekniker personel sayısının yeterli olmadığı görülmüştür. İlk etapta bu sorun üniversitelerin mühendislik, fen ve teknik bilimler fakültelerinden mezun kişilerin, ÇSGB tarafından yetkilendirilmiş kuruluşlarca eğitim verilerek iş güvenliği uzmanlığ1 sınavlarından başarılı olanlar ile çözülmeye çalışılmıștır. Ancak ihtiyacın büyüklüğünden kaynaklı birçok vakıf ve devlet üniversitesinde ISG ön lisans programları açılmıştır. İSG ön lisans program sayısındaki artış bazı sıkıntıları da beraberinde getirmiştir. Her üniversite akademisyen kadrosuna göre kendi ders programlarını oluşturmuş, bu durum da ISG ön lisans eğitiminde belli bir standarda değil farklılıklara yol açmıştır.

$\mathrm{Bu}$ araştırmada, Türkiye'de ön lisans düzeyinde İSG eğitimi veren üniversitelerin programları incelenerek çeşitlilik gösteren İSG programları arasında bir birlikteliğin var olup olmadiğ 1 ve İSG ön lisans eğitiminin mevcut durumunun belirlenmesi amaçlanmıştır.

\section{MATERYAL VE METOT}

\section{Araştırmanın Tipi}

İSG ön lisans eğitiminin mevcut durumu, üniversitelerin Bologna Bilgi Sistemi ve ders programları içerik analizi yöntemiyle taranarak belirlenmiştir. İçerik analizi, "bir metindeki değişkenleri ölçmek amacıyla sistematik, tarafsız ve sayısal olarak yapilan analizdir" şeklinde tanımlanmaktadır. Başka bir deyişle içerik analizi, "sözlü veya yazılı bir metin veya sembolün analiz edilerek rakamlara dönüştürülmesi ve bu rakamların yorumlanmasıdır" şeklinde ifade edilmektedir. ${ }^{16}$

\section{Araştırmanın Evreni ve Örneklemi}

Araştırmanın evrenini Türkiye genelinde İSG eğitimi veren MYO'ların Bologna Bilgi Sistemi ve ders programları oluşturmaktadır. Araştırmanın örneklemi için herhangi bir seçim yöntemine gidilmemiş, tüm evrene ulaşılması hedeflenmiştir. İSG eğitimi veren 99 MYO'dan ulaşılabilen 78 MYO'nun Bologna Bilgi Sistemi ve ders programları araştırmanın örneklemini oluşturmuştur.

\section{Araştırma Verilerin Toplanması ve Analizi}

Türkiye'deki 78 MYO'nun ders planı ve ders içeriği, internet verilerine (Bologna Bilgi Sistemi ve ders programları) dayanılarak incelenmiştir. İnternet üzerinden ulaşılan dersler, dönem (birinci, ikinci, üçüncü, dördüncü), zorunlu-seçmeli, ulusal kredi- Avrupa Kredi Transfer Sistemi (AKTS) ve içerik açısından incelenmiş ve tasnif edilmiştir. $\mathrm{Bu}$ verilerin toplanma ve analizinde içerik analizi yöntemi kullanılmıştır. Bologna Sürecine dâhil olan üniversitelerin, oluşturdukları ders programlarındaki derslerin en az $\% 25$ 'inin (30 AKTS) seçmeli olması kriteri 
bakımından bir dönüşümün gerçekleşip gerçekleşmediğini tespit edebilmek için ders programları değerlendirilmiştir.

\section{Araştırmanın Etik Yönü}

$\mathrm{Bu}$ araştırmada "Yükseköğretim Kurumları Bilimsel Araştırma ve Yayın Etiği Yönergesi" kapsamında uyulması belirtilen tüm kurallara uyulmuştur. Yönergenin ikinci bölümü olan "Bilimsel Araştırma ve Yayın Etiğine Aykırı Eylemler" başlığı altında belirtilen eylemlerden hiçbiri gerçekleştirilmemiştir. Makale "2020 y1lı öncesi araştırma verileri kullanılması ve doktora çalışmasından üretilmesi" sebebiyle etik kurul gerektirmeyen çalışmalar arasında yer almaktadır.

\section{Araștırmanın Sınırlılıkları}

$\mathrm{Bu}$ araştırma, Bologna Bilgi Sistemi ve ders program verilerinin güncel ve doğru olması ile sinırlıdır. Türkiye'deki 99 MYO'dan ulaşılabilen 78 MYO'nun Bologna Bilgi Sistemi ve ders programları değerlendirilmiştir. Programların yeni açılması ve üniversitelerin Bologna Bilgi Sistemi ve ders programlarına erişilememesinden dolayı $21 \quad$ MYO araştırmanın sınırlılıkları arasında yer almaktadır. İSG eğitimi veren MYO'ların Bologna Bilgi Sistemi ve ders programlar1 15 Haziran 2019-15 Eylül 2019 tarihleri arasında incelenmiştir. Araştırmada bu süre aralığında araştırma kapsamındaki üniversitelerde okutulan dersler dikkate alındığından, yapılan araştırma işleminden sonra ilgili programlarda yenileme/değişiklik yapılmış olabilir.

\section{BULGULAR VE TARTIŞMA}

Türkiye'deki 84 üniversitenin İSG eğitimi veren 99 MYO'sunun ders programları incelenmiştir. Bazı üniversitelerin Bologna Bilgi Sistemi ve ders programlarına ulaşılamadığı için $78 \mathrm{MYO}$ analiz kapsamına dâhil edilerek programların benzer ve farklı yönleri tespit edilmiştir. 78 programın bütün dersleri gerek ulusal gerekse AKTS ders kredileri, okutuldukları dönemler, zorunluseçmeli durumları, ders adlandırma farklılıkları, teorik ve uygulama durumları, programlara göre ders sayıları tablolara dönüştürülerek tasnif edilmiştir.

Üniversitelerin İSG teknikeri yetiștiren programlarının internet sayfalarında verdikleri bilgilerin ve Bologna Bilgi Sistemi'nin incelenmesi sonucunda ders programlarında bulunan dersler ve içeriklerin birbirinden oldukça farklı olduğu tespit edilmiştir. Programlar incelendiğinde derslere verilen ulusal ve AKTS kredi farklılıkları, dersin teori-uygulama kredi oranları, zorunlu-seçmeli durumları ve okutuldukları dönemlerdeki farklılıklar dikkat çekmektedir.

Araştırma zorunlu-seçmeli ders açısından incelendiğinde, İSG ön lisans programlarında yer alan derslerin bazı MYO'larda zorunlu dersler kategorisinde yer aldığı, bazı MYO'larda ise seçmeli dersler kategorisinde kabul edildiği görülmektedir. Örneğin "Çevre" ile ilgili dersleri programına zorunlu olarak koyan $13(\% 16,67)$ MYO vardır. Buna karşın $21(\% 26,92)$ MYO seçmeli ders olarak programlarında "Çevre" ile ilgili derslere yer vermiştir. $44(\% 56,41)$ MYO ise ya programlarında bu derse yer vermemiş ya da başka bir dersin içerisinde bu konuya değinmiştir. 5 MYO'da zorunlu, 11 MYO'da seçmeli olmak üzere toplam 16 MYO "Kayıt ve Raporlama" ile ilgili dersleri programına alırken, 62 MYO bu dersleri programına almamıştır.

Araştırma ulusal ve AKTS kredileri açısından incelendiğinde, MYO'ların verdikleri ulusal ve AKTS kredi farklılıkları dikkat çekmektedir. Örneğin "Makine ve Teçhizat" ile ilgili derslere 60 MYO programinda yer verirken 18 MYO bu dersleri programına almamıştır. $\mathrm{Bu}$ dersi programlarına alan MYO'lardan 4'ü 2 AKTS, 16's1 3 AKTS, 15'i 4 AKTS, 4'ü 5 AKTS, 7'si 6 AKTS, 2'si 7 AKTS, 5'i 8 AKTS, 4'ü 10 AKTS, 2'si 11 AKTS, 1'i 12 AKTS olarak belirlemiştir. "Risk Analizi ve 
Metotları" ile ilgili dersleri Bergama MYO 3 AKTS, Gediz MYO 4 AKTS, Çavdır MYO 5 AKTS, Gedik MYO 6 AKTS, Ağrı İbrahim Çeçen MYO 8 AKTS ve Gümüşova MYO 9 AKTS olarak belirlemiştir.

Araştırma derslerin verildiği dönem açısından incelendiğinde, derslerin MYO'lara göre farklı yarıyıllarda yer aldığ tespit edilmiştir. Örneğin "Kişisel Koruyucu Donanımlar" ile ilgili derslere Anadolu BİL MYO 1. dönem, Oğuzeli MYO 2. dönem, Hilvan MYO 3. dönem ve Borçka Acarlar MYO 4. dönem programında yer vermiştir. $\mathrm{Bu}$ derse $27 \mathrm{MYO}$ ya programlarında yer vermemiş ya da başka bir dersin içerisinde bu konuya değinmiştir. $\mathrm{Bu}$ derse $43 \mathrm{MYO}$ programinda sadece bir dönemde yer verirken, 8 MYO 2 dönemde de yer vermiştir. $\mathrm{Bu}$ dersi programına alan MYO'ların \%11,86's1 (7) 1. döneminde, \%15,25'i (9) 2. döneminde, \%49,15'i (29) 3. döneminde ve $\% 23,73$ 'ü (14) 4. döneminde yer vermiştir.

Araştırma derslerin işlenişi açısından incelendiğinde, İSG ön lisans programında yer alan dersler teorik, uygulama ve teorik + uygulama olma durumlarına göre belirlenmiştir. Örneğin 42 MYO "Risk Analizi ve Metotları" ile ilgili dersleri ulusal kredisi 2, 3 veya 4 teorik olarak programına alırken, 27 MYO bu dersleri teori + uygulama kredisi $1+1,1+2,2+1,2+2$ ve $3+1$ olarak programına almıştır.

Araştırma ders sayıları açısından incelendiğinde, ders sayısıyla ilgili değerlendirme yaparken birçok dersin I ve II şeklinde iki dönemde verildiği görülmektedir. Örneğin "Makine ve Teçhizat" ile ilgili derslere 18 MYO I ve II şeklinde iki döneminde yer verirken $18 \mathrm{MYO}$ bu konuya ya hiç yer ayırmamış ya da başka bir dersin içerisinde bu konuya değinmiştir. 42 MYO ise sadece bir döneminde bu derslere yer vermiştir.
Tablo 1'de Türkiye'de İSG eğitimi veren MYO'ların programlarında yer alan derslerin dönemsel, zorunlu ve seçmeli ders sayılarının dağılımı yer almaktadır. MYO'lar incelendiğinde eğitim planlarında yer alan ders sayılarının değişiklik gösterdiği tespit edilmiştir. Toplam ders sayılarının vakıf üniversitelerinde daha az olması dikkat çekmektedir. Beykent Üniversitesi MYO'sunda toplam 25 ders varken Çukurova Üniversitesi Karaisalı MYO ve Kahramanmaraş Sütçü İmam Üniversitesi Afşin MYO'da 47 ders olduğu tespit edilmiştir.

İSG ön lisans programları zorunlu ders sayısına göre dağılımları incelendiğinde, zorunlu ders sayısı 17-40 arasinda değişmektedir. Zorunlu ders sayısının en yüksek olduğu program Yapraklı MYO'dur. Yaprakl1 MYO'yu 38 ders ile Karaisalı MYO, Afşin MYO ve Boyabat MYO takip etmektedir. En az sayıda zorunlu dersi İzmir Kavram MYO (17) vermektedir. Beykent MYO (18), Üsküdar Sağlık Hizmetleri MYO (21), Gediz MYO (21), Pazarlar MYO (21) ve İstanbul Şehir MYO (22) zorunlu ders sayılarının düşük olduğu diğer programlardır. Ataşehir Adıgüzel, Doğuş, Üsküdar Sağlık Hizmetleri, Esenyurt, Altınbaş, İstanbul (Uzaktan Eğitim), Nişantaşı, Çă̆ MYO'larda bütün dersler zorunludur (Tablo 1).

Seçmeli ders uygulamasının yaygın bir uygulama olduğu görülmekle birlikte 8 MYO'da seçmeli ders uygulamasının olmadığ1 tespit edilmiştir. Diğer 70 programın seçmeli ders sayısı, 1-16 arasında değişmektedir. Seçmeli ders sayısının en yüksek olduğu program Eflani MYO'dur. Eflani MYO'yu 13 ders ile Hitit Teknik Bilimler MYO takip etmektedir. Toros MYO (1), İstanbul Arel MYO (2), Anadolu BİL MYO (2), Karaman Teknik Bilimler MYO (2), Araklı MYO (2), Beykoz MYO (2) ve Adapazarı MYO (2) seçmeli derslerin en az olduğu programlardır (Tablo 1). 
Tablo 1. Türkiye'de İSG Eğitimi Veren MYO’ların Programlarında Yer Alan Derslerin Dönemsel, Zorunlu Ve Seçmeli Ders Sayılarının Dağılımı
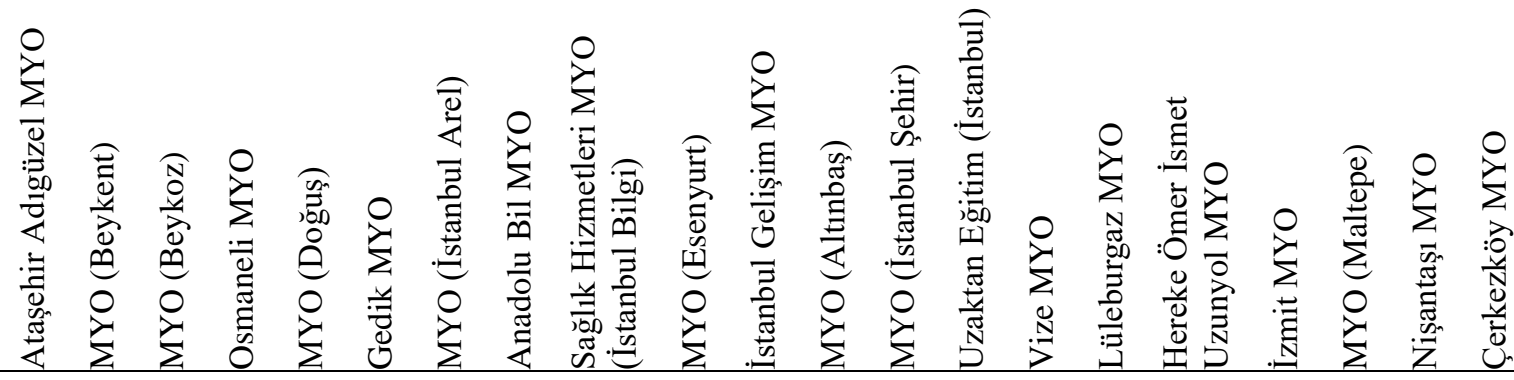

\begin{tabular}{rrrrrrrrrrrrrrrrrrrrrr}
\hline $\mathbf{1}$ & 7 & 7 & 10 & 10 & 7 & 7 & 9 & 9 & 9 & 7 & 8 & 6 & 8 & 7 & 8 & 8 & 10 & 10 & 8 & 8 & 11 \\
\hline $\mathbf{2}$ & 8 & 6 & 8 & 10 & 6 & 7 & 9 & 10 & 8 & 7 & 7 & 6 & 8 & 7 & 9 & 9 & 9 & 9 & 9 & 8 & 11 \\
\hline $\mathbf{3}$ & 6 & 6 & 3 & 11 & 6 & 7 & 7 & 9 & 7 & 7 & 6 & 6 & 7 & 6 & 7 & 7 & 10 & 10 & 8 & 7 & 8 \\
\hline $\mathbf{4}$ & 6 & 4 & 8 & 6 & 4 & 7 & 7 & 10 & 4 & 8 & 6 & 6 & 7 & 6 & 8 & 8 & 10 & 10 & 8 & 8 & 9 \\
\hline $\mathbf{Z}$ & 27 & 19 & 27 & 26 & 23 & 24 & 30 & 36 & 28 & 29 & 20 & 24 & 22 & 26 & 26 & 26 & 31 & 31 & 29 & 31 & 30 \\
\hline $\mathbf{S}$ & 0 & 4 & 2 & 11 & 0 & 4 & 2 & 2 & 0 & 0 & 7 & 0 & 8 & 0 & 6 & 6 & 8 & 8 & 4 & 0 & 9 \\
\hline $\mathbf{T}$ & 27 & 23 & 29 & 37 & 23 & 28 & 32 & 38 & 28 & 29 & 27 & 24 & 30 & 26 & 32 & 32 & 39 & 39 & 33 & 31 & 39 \\
\hline
\end{tabular}
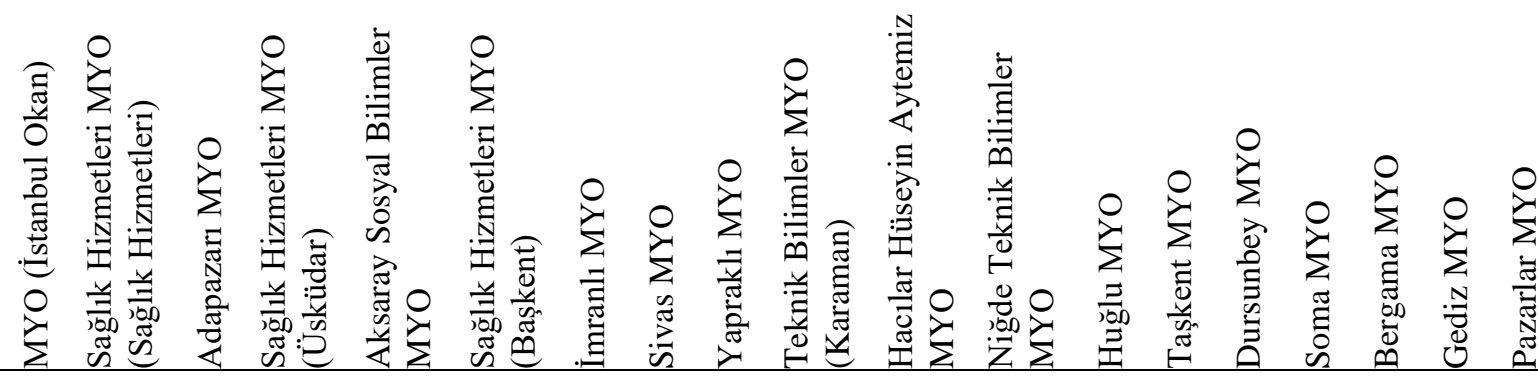

\begin{tabular}{rrrrrrrrrrrrrrrrrrrr}
\hline $\mathbf{1}$ & 8 & 10 & 8 & 10 & 10 & 10 & 11 & 12 & 11 & 8 & 8 & 9 & 10 & 10 & 10 & 8 & 9 & 8 & 8 \\
\hline $\mathbf{2}$ & 8 & 9 & 8 & 10 & 10 & 10 & 13 & 13 & 11 & 8 & 9 & 9 & 10 & 10 & 10 & 8 & 8 & 8 & 8 \\
\hline $\mathbf{3}$ & 7 & 7 & 6 & 6 & 9 & 9 & 11 & 11 & 11 & 6 & 9 & 8 & 8 & 8 & 9 & 8 & 11 & 7 & 7 \\
\hline $\mathbf{4}$ & 6 & 7 & 6 & 5 & 8 & 5 & 9 & 10 & 11 & 5 & 9 & 8 & 8 & 8 & 9 & 4 & 12 & 8 & 8 \\
\hline $\mathbf{Z}$ & 25 & 29 & 25 & 21 & 27 & 24 & 34 & 36 & 40 & 25 & 31 & 26 & 26 & 27 & 28 & 24 & 28 & 21 & 21 \\
\hline $\mathbf{S}$ & 4 & 4 & 3 & 10 & 10 & 10 & 10 & 10 & 4 & 2 & 4 & 8 & 10 & 9 & 10 & 4 & 12 & 10 & 10 \\
\hline $\mathbf{T}$ & 29 & 33 & 28 & 31 & 37 & 34 & 44 & 46 & 44 & 27 & 35 & 34 & 36 & 36 & 38 & 28 & 40 & 31 & 31 \\
\hline
\end{tabular}

\begin{tabular}{|c|c|c|c|c|c|c|c|c|c|c|c|c|c|c|c|c|c|c|c|c|}
\hline & 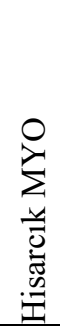 & 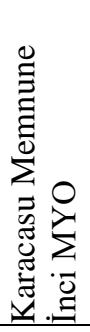 & 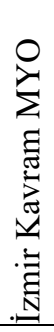 & 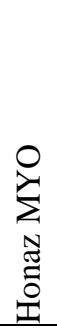 & 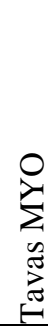 & 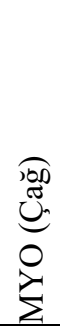 & 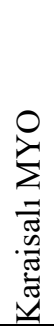 & 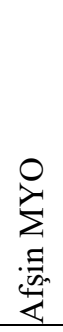 & 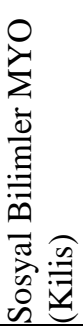 & 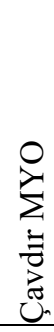 & $\begin{array}{l}0 \\
\sum \\
\sum \\
0 \\
0 \\
0 \\
0\end{array}$ & 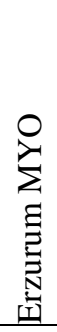 & 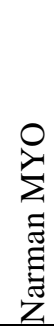 & 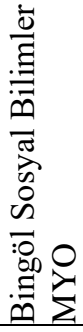 & 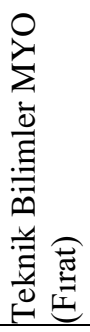 & 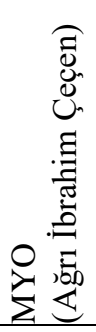 & 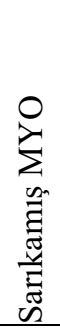 & 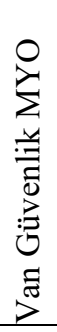 & $\begin{array}{l}0 \\
\sum \\
\vdots \\
0 \\
000 \\
0 \\
0 \\
0 \\
0 \\
0 \\
\overline{0} \\
\bar{z} \\
\end{array}$ & 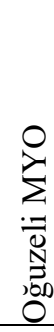 \\
\hline 1 & 9 & 11 & 7 & 9 & 11 & 6 & 12 & 12 & 10 & 10 & 9 & 10 & 10 & 9 & 11 & 10 & 10 & 10 & 12 & 12 \\
\hline 2 & 9 & 12 & 6 & 9 & 11 & 6 & 13 & 12 & 10 & 9 & 10 & 10 & 10 & 9 & 10 & 11 & 10 & 10 & 11 & 11 \\
\hline 3 & 8 & 11 & 7 & 9 & 9 & 6 & 10 & 12 & 10 & 10 & 9 & 7 & 7 & 8 & 10 & 7 & 10 & 9 & 8 & 11 \\
\hline 4 & 8 & 10 & 6 & 2 & 8 & 6 & 13 & 11 & 10 & 9 & 7 & 7 & 7 & 7 & 10 & 7 & 11 & 10 & 8 & 10 \\
\hline $\mathrm{Z}$ & 26 & 32 & 17 & 24 & 29 & 24 & 38 & 38 & 28 & 29 & 34 & 25 & 25 & 24 & 35 & 31 & 33 & 28 & 35 & 36 \\
\hline$S$ & 8 & 12 & 9 & 5 & 10 & 0 & 10 & 9 & 12 & 9 & 1 & 9 & 9 & 9 & 6 & 4 & 8 & 11 & 4 & 8 \\
\hline $\mathrm{T}$ & 34 & 44 & 26 & 29 & 39 & 24 & 48 & 47 & 40 & 38 & 35 & 34 & 34 & 33 & 41 & 35 & 41 & 39 & 39 & 44 \\
\hline
\end{tabular}


Tablo 1. (Devamı) Türkiye’de İSG Eğitimi Veren MYO’ların Programlarında Yer Alan Derslerin Dönemsel, Zorunlu Ve Seçmeli Ders Sayılarının Dağılımı

\begin{tabular}{|c|c|c|c|c|c|c|c|c|c|c|c|c|c|c|c|c|c|c|}
\hline & 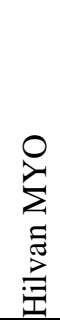 & 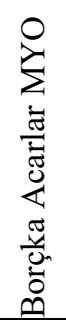 & $\begin{array}{l}0 \\
\sum \\
\sum \\
\substack{0 \\
0 \\
0} \\
0\end{array}$ & $\begin{array}{l}0 \\
\sum \\
\vdots \\
0 \\
\stackrel{0}{0} \\
\Sigma\end{array}$ & 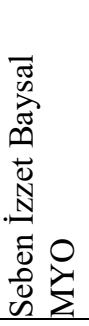 & 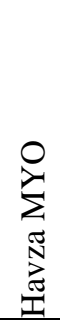 & 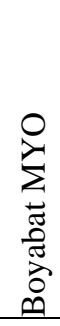 & 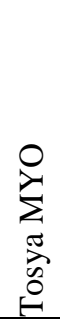 & $\begin{array}{l}0 \\
\sum \\
\Sigma \\
\bar{z} \\
\frac{\pi}{\pi} \\
\frac{\pi}{2}\end{array}$ & 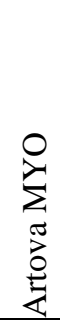 & 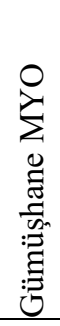 & $\begin{array}{l}0 \\
\sum \\
\sum \\
\dot{0} \\
\dot{0} \\
\nu\end{array}$ & 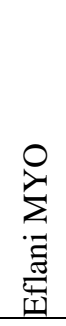 & 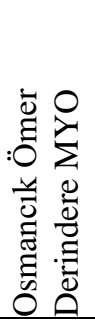 & 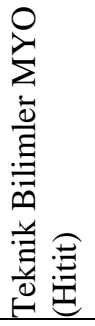 & 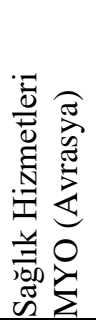 & $\begin{array}{l}0 \\
\sum \\
\sum \\
0 \\
0 \\
0 \\
: \Xi \\
: \Xi \\
0 \\
0\end{array}$ & 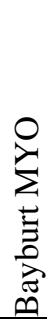 \\
\hline 1 & 11 & 9 & 11 & 11 & 10 & 9 & 11 & 10 & 8 & 9 & 8 & 12 & 12 & 10 & 10 & 9 & 11 & 9 \\
\hline 2 & 12 & 10 & 11 & 12 & 11 & 9 & 10 & 11 & 8 & 9 & 8 & 11 & 11 & 10 & 10 & 8 & 11 & 9 \\
\hline 3 & 11 & 8 & 11 & 10 & 11 & 9 & 11 & 9 & 8 & 7 & 9 & 8 & 12 & 10 & 10 & 8 & 8 & 8 \\
\hline 4 & 12 & 9 & 3 & 8 & 10 & 8 & 10 & 11 & 8 & 7 & 9 & 11 & 11 & 10 & 10 & 7 & 7 & 9 \\
\hline $\mathbf{Z}$ & 38 & 30 & 28 & 37 & 33 & 29 & 38 & 33 & 30 & 27 & 26 & 30 & 30 & 32 & 27 & 25 & 27 & 25 \\
\hline $\mathbf{S}$ & 8 & 6 & 8 & 4 & 9 & 6 & 4 & 8 & 2 & 5 & 8 & 12 & 16 & 8 & 13 & 7 & 10 & 10 \\
\hline $\mathbf{T}$ & 46 & 36 & 36 & 41 & 42 & 35 & 42 & 41 & 32 & 32 & 34 & 42 & 46 & 40 & 40 & 32 & 37 & 35 \\
\hline
\end{tabular}

1: 1. Sinıf 1. Dönem Toplam Ders Sayısı; 2: 1. Sinıf 2. Dönem Toplam Ders Sayısı; 3: 2. Sınıf 1. Dönem Toplam Ders Sayısı; 4: 2 . Sınıf 2. Dönem Toplam Ders Sayısı; Z: Toplam Zorunlu Ders Sayısı; S: Toplam Seçmeli Ders Sayısı; T: Toplam Ders Sayısı.

Tablo 2'de Türkiye'de İSG eğitimi veren MYO'ların programlarında yer alan zorunlu ve seçmeli derslerin AKTS dağılımları yer almaktadır. Tablo 2 incelendiğinde AKTS standartlarına göre toplamda 120 AKTS ders olmas1 gereken ön lisans eğitiminde, incelenen 78 programın ortalama 120 AKTS ile standartlara uygun olduğu tespit edilmiştir. Standardın altında en az AKTS ile Erzurum MYO (112) iken standardın üzerinde ve en fazla ders AKTS kredisi olan Eflani MYO ve İstanbul Şehir MYO'dur. Toplam AKTS 120'den az olanlar, Van Güvenlik MYO (119) ve Sivas MYO'dur (115). AKTS 120'den fazla olanlar ise Seben İzzet Baysal MYO (121), Ağr1 İbrahim Çeçen MYO (123), Merzifon MYO (126) ve Beykoz MYO'dur (127).

Programların içinde en az zorunlu ders AKTS kredisine, 84 AKTS ile İzmir Kavram ve Tavas MYO sahipken, en fazla zorunlu ders AKTS kredisine 121 AKTS ile Beykoz MYO sahiptir. Seçmeli derslerde (derslerin hepsi zorunlu olan MYO'lar hariç) ise program içerisinde öğrencilerine en az seçmeli ders kredisi veren MYO Toros (3) iken en fazla seçmeli ders veren Gediz, Pazarlar ve İzmir Kavram (36) MYO'dur. Gediz, Pazarlar ve İzmir Kavram MYO'yu İstanbul Gelişim MYO (35), Eflani MYO
(34), Hitit Teknik Bilimler MYO (34), Çerkezköy MYO takip etmektedir. Anadolu BİL MYO (4), Araklı MYO (6), İstanbul Arel MYO (6), Beykoz MYO (6) ve Gedik MYO (8) seçmeli ders kredilerinin düşük olduğu diğer programlardır (Tablo 2).

Programlardaki seçmeli ders AKTS'lerinin toplam AKTS kredisine oranının \%0-30 arasında değiştiği belirlenmiştir. Seçmeli ders oranının en yüksek olduğu programlar; Pazarlar, Gediz, Tavas ve İzmir Kavram MYO'dur (\%30). Bu programları İstanbul Gelişim MYO $(\% 29,2)$, Hitit Teknik Bilimler MYO (\%28,3), Çerkezköy MYO $(\% 27,5)$ ve Erzurum MYO $(\% 26,8)$ takip etmektedir. Ayrica 9 programda hiç bir seçmeli dersin olmadığ 19 programın ise seçmeli ders oranının \%10'un altında olduğu tespit edilmiştir (Tablo 2). 


\section{Tablo 2. Türkiye'de İSG Eğitimi Veren MYO’ların Programlarında Yer Alan Zorunlu Ve Seçmeli Derslerin AKTS Dağılımı}

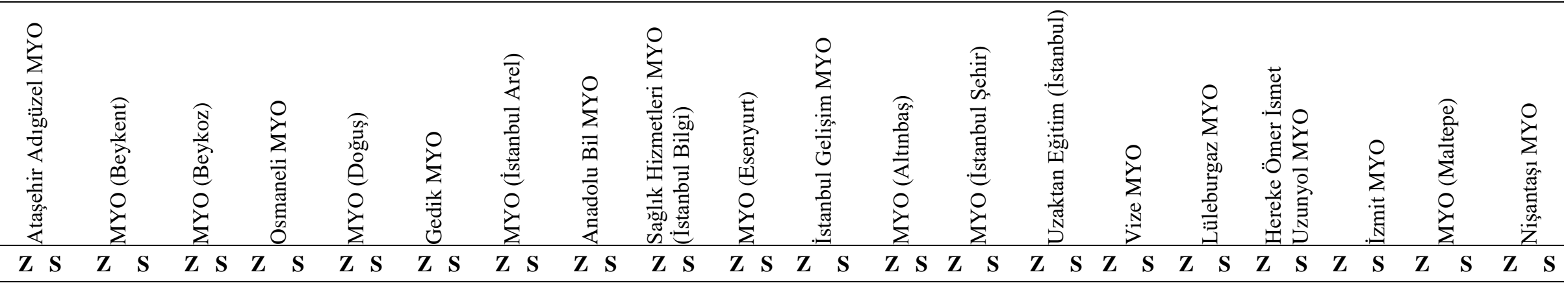

\begin{tabular}{|c|c|c|c|c|c|c|c|c|c|c|c|c|c|c|c|c|c|c|c|c|c|c|c|c|c|c|c|c|c|c|c|c|c|c|c|c|c|c|c|c|}
\hline 1 & 30 & & 30 & 0 & 38 & 0 & 19 & 11 & 30 & 0 & 30 & 0 & 27 & 3 & 30 & 0 & 31 & 0 & 30 & 0 & 30 & 0 & 30 & 0 & 30 & 0 & 30 & 0 & 30 & 0 & 30 & 0 & 30 & 0 & 30 & 0 & 28 & 2 & 30 & 0 \\
\hline 2 & 30 & 0 & 26 & 4 & 26 & 3 & 28 & 2 & 30 & 0 & 30 & 0 & 27 & 3 & 30 & 0 & 29 & 0 & 30 & 0 & 30 & 0 & 30 & 0 & 38 & 0 & 30 & 0 & 30 & 0 & 30 & 0 & 30 & 0 & 30 & 0 & 30 & 0 & 30 & 0 \\
\hline 3 & 30 & 0 & 16 & 14 & 30 & 0 & 12 & 18 & 30 & 0 & 26 & 4 & 30 & 0 & 28 & 2 & 30 & c & 30 & 0 & 15 & 15 & 30 & 0 & 15 & 15 & 30 & 0 & 20 & 10 & 20 & 10 & 15 & 15 & 15 & 15 & 24 & 6 & 30 & 0 \\
\hline 4 & 30 & 0 & 30 & 0 & 27 & 3 & 30 & 0 & 30 & 0 & 26 & 4 & 30 & 0 & 28 & 2 & 30 & 0 & 30 & 0 & 10 & 20 & 30 & 0 & 15 & 15 & 30 & 0 & 18 & 12 & 18 & 12 & 15 & 15 & 15 & 15 & 27 & 2 & 30 & 0 \\
\hline $\mathbf{T}$ & 120 & 0 & 102 & 18 & 121 & 6 & 89 & 31 & 120 & 0 & 112 & 8 & 114 & 6 & 116 & 4 & 120 & 0 & 120 & 0 & 85 & 35 & 120 & 0 & 98 & 30 & 120 & 0 & 98 & 22 & 98 & 22 & 90 & 30 & 90 & 30 & 109 & 11 & 120 & 0 \\
\hline & & & & 15.0 & & & & 25.8 & $\% 0$. & & & & & & $\%$ ? & & & & & & $\% 2$ & & 0 & & & & $\% 0$. & & $\% 1$ & & & & & & & & $\% 9$ & & $\% 0.0$ & \\
\hline
\end{tabular}

\begin{tabular}{|c|c|c|c|c|c|c|c|c|c|c|c|c|c|c|c|c|c|c|c|c|c|c|c|c|c|c|c|c|c|c|c|c|c|c|c|c|c|c|c|c|}
\hline & 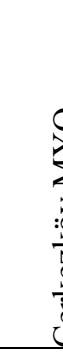 & 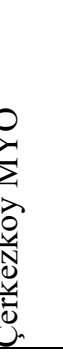 & 3 & 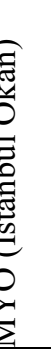 & 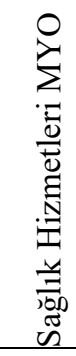 & & 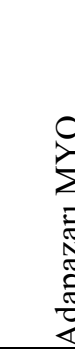 & & 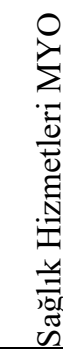 & $\overparen{E}$ & 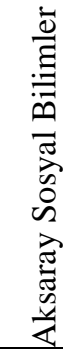 & $\underbrace{0}_{\Sigma}$ & 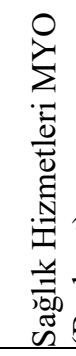 & 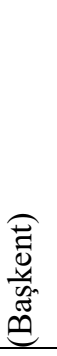 & 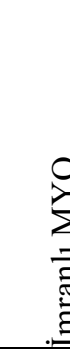 & 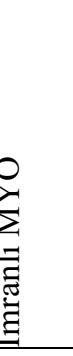 & $\begin{array}{l}0 \\
\sum \\
\infty \\
\infty \\
\infty\end{array}$ & & 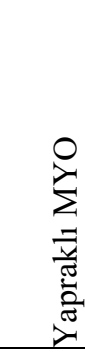 & & 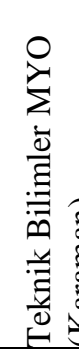 & & 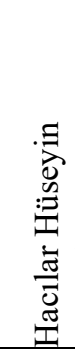 & 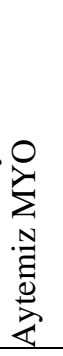 & 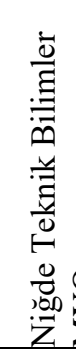 & & $\begin{array}{l}2 \\
\sum \\
0 \\
0 \\
0\end{array}$ & 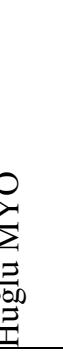 & 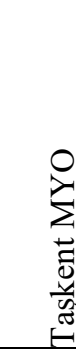 & & 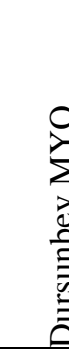 & & 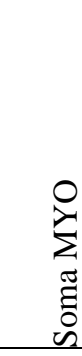 & & 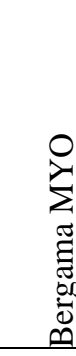 & 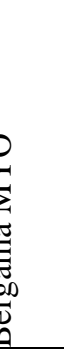 & 2 & 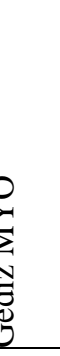 & 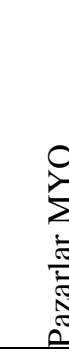 & 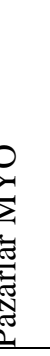 \\
\hline & $\mathbf{Z}$ & $\mathbf{S}$ & $\mathbf{Z}$ & $\mathbf{S}$ & $\mathbf{Z}$ & $\mathbf{S}$ & $\mathbf{Z}$ & $\mathbf{S}$ & $\mathbf{Z}$ & $\mathbf{S}$ & $\mathbf{Z}$ & $\mathbf{S}$ & $\mathbf{Z}$ & $\mathbf{S}$ & $\mathbf{Z}$ & $\mathbf{S}$ & $\mathbf{Z}$ & $\mathbf{S}$ & $\mathbf{Z}$ & $\mathbf{S}$ & $\mathbf{Z}$ & $\mathbf{S}$ & $\mathbf{Z}$ & $\mathbf{S}$ & $\mathbf{Z}$ & $\mathbf{S}$ & $\mathbf{Z}$ & $\mathbf{S}$ & $\mathbf{Z}$ & $\mathbf{S}$ & $\mathbf{Z}$ & $\mathbf{S}$ & $\mathbf{Z}$ & $\mathbf{S}$ & $\mathbf{Z}$ & $\mathbf{S}$ & $\mathbf{Z}$ & $\mathbf{S}$ & $\mathbf{Z}$ & $\mathbf{S}$ \\
\hline 1 & 27 & 3 & 30 & 0 & 30 & 0 & 30 & 0 & 22 & 6 & 30 & 0 & 21 & 6 & 24 & 6 & 24 & 5 & 27 & 3 & 30 & 0 & 30 & 0 & 30 & 0 & 30 & 0 & 30 & 0 & 30 & 0 & 30 & 0 & 30 & 0 & 28 & 2 & 28 & 2 \\
\hline 2 & 28 & 2 & 30 & 0 & 28 & 2 & 25 & 5 & 25 & 7 & 30 & 0 & 27 & 6 & 24 & 6 & 24 & 4 & 24 & 6 & 30 & 0 & 30 & 0 & 30 & 0 & 22 & 8 & 26 & 4 & 23 & 7 & 25 & 5 & 30 & 0 & 28 & 2 & 28 & 2 \\
\hline 3 & 14 & 16 & 19 & 11 & 27 & 3 & 25 & 5 & 24 & 8 & 15 & 15 & 21 & 9 & 18 & 12 & $\begin{array}{ll}17 & 1 \\
\end{array}$ & 11 & 30 & 0 & 28 & 2 & 22 & 8 & 14 & 16 & 24 & 6 & 24 & 6 & 18 & 12 & 21 & 9 & 15 & 15 & 14 & 16 & 14 & 16 \\
\hline 4 & 18 & 12 & 18 & 12 & 22 & 8 & 25 & 5 & 21 & 7 & 15 & 15 & 21 & 9 & 24 & 6 & 24 & 6 & 27 & 3 & 28 & 2 & 22 & 8 & 14 & 16 & 22 & 8 & 22 & 8 & 17 & 13 & 30 & 0 & 15 & 15 & 14 & 16 & 14 & 16 \\
\hline $\mathbf{T}$ & 87 & 33 & 97 & 23 & 107 & 13 & 105 & 15 & 92 & 28 & 90 & 30 & 90 & 30 & 90 & 30 & 892 & 26 & 108 & 12 & 116 & 4 & 104 & 16 & 88 & 32 & 98 & 22 & 102 & 18 & 88 & 32 & 106 & 14 & 90 & 30 & 84 & 36 & 84 & 36 \\
\hline SO & $\% 2$ & 27.5 & $\% 1$ & 9.2 & $\% 1$ & 10.8 & $\% 1$ & 2.5 & $\% 2$ & 23.3 & & 25.0 & $\% 25$ & 5.0 & $\% 2$ & 25.0 & $\% 22$. & & $\% 10$ & & $\% 3$ & 3.3 & $\% 1$ & 13.3 & $\% 26$ & 6.7 & $\% 18$ & 8.3 & $\% 15$ & 5.0 & $\% 2$ & 6.7 & $\% 11$ & & $\% 25$ & 5.0 & $\% 3$ & 30.0 & $\% 30$ & 30.0 \\
\hline
\end{tabular}




\section{Tablo 2. (Devamı) Türkiye’de İSG Eğitimi Veren MYO’ların Programlarında Yer Alan Zorunlu Ve Seçmeli Derslerin AKTS Dağılımı}

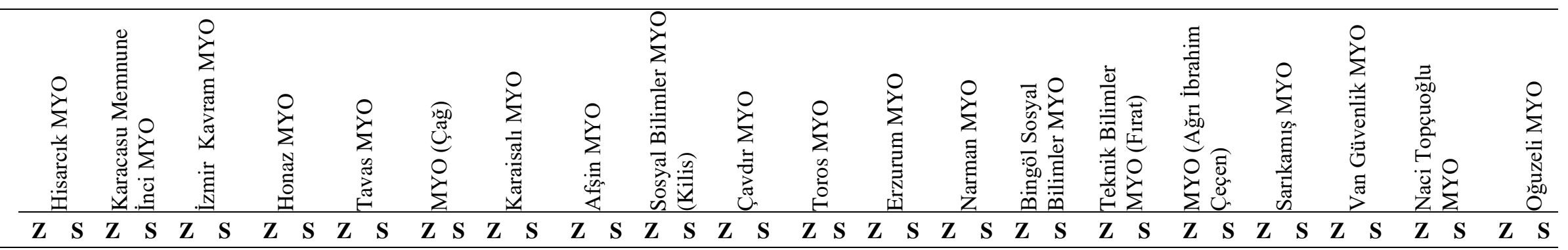

\begin{tabular}{|c|c|c|c|c|c|c|c|c|c|c|c|c|c|c|c|c|c|c|c|c|c|c|c|c|c|c|c|c|c|c|c|c|c|c|c|c|c|c|c|c|}
\hline 1 & & 0 & & & & & 24 & 6 & 0 & 10 & 30 & Q & 26 & 4 & 20 & 4 & 24 & 6 & 24 & 6 & 30 & 0 & 24 & 6 & 24 & 6 & 24 & 6 & 30 & & 25 & 5 & 30 & 0 & 27 & 3 & 29 & 1 & 30 & \\
\hline 2 & & 0 & & 0 & & 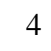 & & 8 & & & 30 & 0 & 21 & , & & ? & & & & & & 0 & & & & & & & & & & & & & & & & & & \\
\hline 3 & & & & 0 & & & 26 & 4 & 27 & 8 & 30 & 0 & 24 & 6 & & 6 & & 9 & & 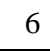 & 30 & 0 & 24 & & 24 & & 24 & & & & & & 18 & 12 & & & & 13 & & \\
\hline 4 & & & & & & & & 0 & & 8 & & 0 & 21 & & & & & & & & & 3 & 14 & 12 & 18 & 12 & 19 & & & & & & 18 & 12 & & & 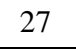 & & 22 & \\
\hline $\mathbf{T}$ & & $J 2$ & & & & 0 & & & & 30 & & 0 & 92 & & & & & & & 25 & & 3 & & & & 30 & & 27 & & & & & & & & & & 17 & 102 & \\
\hline & & & & & & & & & & & & & & & & & & & & & & & & & & & & & & & & & & & & & & & & \\
\hline
\end{tabular}

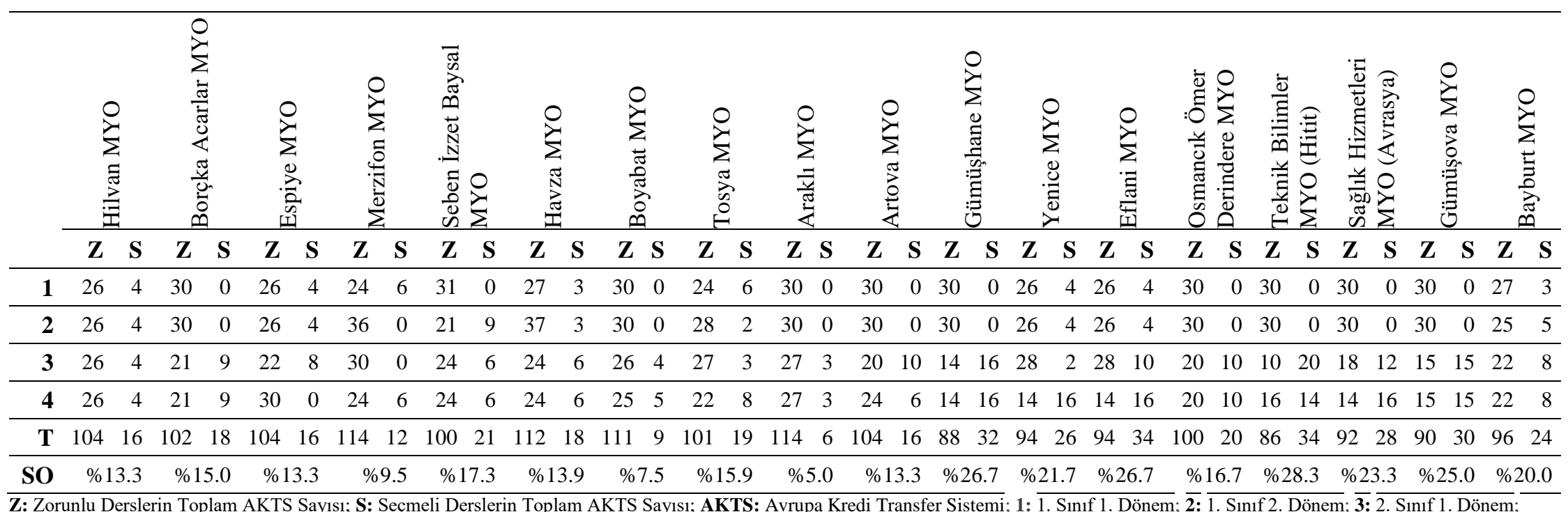

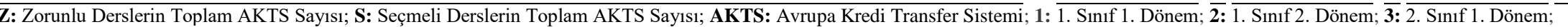

4: 2. Sinıf 2. Dönem; T: Toplam AKTS sayısi; SO: Seçmeli Derslerin AKTS Yüzdesi. 
ISG ön lisans programlarının incelendiği bu araştırma, Türkiye'de İSG ile ilgili program analizi konusunda yayımlanan ilk çalışma olması açısından önem arz etmektedir. Türkiye'de ön lisans düzeyinde İSG eğitimi veren program sayısının her geçen yıl artması, bu programlarda öğrenim gören öğrenci ve mezun olan tekniker sayısında da önemli artışlara neden olmuştur. Ayrıca günümüzde İSG'ye olan ihtiyacın artması da bu programlara olan rağbeti yükseltmiştir. $\mathrm{Bu}$ nedenle İSG ön lisans programlarında verilen eğitimin niteliği büyük önem arz etmektedir. Bu bağlamda Türkiye'deki İSG ön lisans programları incelenerek çeşitlilik gösteren programlar arasında bir birlikteliğin var olup olmadığının tespit edilmesi ve İSG eğitiminin kalitesinin arttırılması için mevcut durumun ortaya konulması hedeflenmiştir.

Eğitimin kalitesine etki eden ve sayısal olarak ölçülebilen faktörlerden bir tanesi öğretim programlarındaki ders dağılımıdır. ${ }^{17}$ Programlardaki ders sayısı, ders saati, ders kredisi, dersin verildiği dönem, dersin zorunlu-seçmeli durumu gibi ölçütler kullanılarak eğitimin kalitesi tespit edilebilmektedir. İSG ön lisans programlarındaki toplam ders sayılarını ve birbirinden farklı derslerin sayılarını belirlemek, kurumlarin birbirlerine oranla ders çeşitliliğini anlama açısından yararlı olacaktır.

Araştırma ders sayıları açısından değerlendirildiğinde, İSG ön lisans programlarındaki ders sayıları 25-47 arasında değiştiği tespit edilmiştir. Toplam ders sayılarının vakıf üniversitelerinde daha az olması dikkat çekmektedir. Zorunlu ders sayısı ise 17-40 arasında değiştiği saptanmıştır. Seçmeli ders kriterinin yaygın bir uygulama olduğu görülmekle birlikte 8 programda seçmeli ders uygulamasının olmadığı ve diğer programların seçmeli ders sayısı 1-16 arasında değiştiği belirlenmiştir (Tablo 1). Buradan hareketle eğitim planlarında yer alan ders sayılarının değişiklik gösterdiği söylenebilir. Bu farklılık ders kredilerinin programların birbirine oranla daha yüksek ya da düşük olmasıyla ve
Bologna Süreci'nde istenilen seçmeli ders kriterine uyulmamasıyla açıklanabilir. Literatürde bu araştırmanın sonuçlarıyla paralel şekilde Sezen (2018) ve Görkem (2013) tarafından yapılan çalışmalarda da öğretim planlarında yer alan ders sayılarının değişiklik gösterdiği saptanmıştır. ${ }^{18,19}$ Kardaş (2020) Türkiye Yükseköğretim Yeterlilikler Çerçevesi kapsamında yaptığ değerlendirme çalışmasında zorunlu ders sayısının fazla olduğu ya da seçmeli ders sayısının az olduğu programlarda bilgi, beceri ve yetkinlik boyutlarında daha fazla saate ulaşıldığ 1 tespit edilmiştir. ${ }^{20}$ Buradan hareketle İSG ön lisans eğitimindeki mevcut programlar yeniden gözden geçirilerek dersler programlara yerleştirilirken Bologna Süreci kapsaminda derslerin kredi hesaplamalarına ve zorunlu-seçmeli durumlarına dikkat edilmesi gerekmektedir.

Araştırma, zorunlu-seçmeli ders açısından değerlendirildiğinde, İSG ön lisans programlarında yer alan derslerin bazı programlarda zorunlu dersler kategorisinde yer aldığı, bazı programlarda ise seçmeli dersler kategorisinde kabul edildiği tespit edilmiştir. Araştırma, derslerin verildiği dönem açısından değerlendirildiğinde ise derslerin programlara göre farklı yarıyıllarda yer aldığ 1 belirlenmiştir. Bu durum ISG eğitimi alan öğrencilerin bazı dersleri alıp bazı dersleri alamamalarına ve mesleğin anlaşılması açısından bazı sıkıntılara neden olduğu söylenebilir. Bir dersin hangi dönemde kaç saatte verildiği ve zorunluseçmeli durumu nitelikli İSG teknik elemanı yetiştirilmesi bakımından önem arz etmektedir. Literatürde bu araştırma ile benzerlik gösteren çalışmalarda da [Sezen (2018), Kardaş (2020), Türten Kaymaz vd. (2017), Sağlam vd. (2015), Kavak vd. (2015), Dalkılıç (2015), Erdurak (2016)] zorunlu-seçmeli derslerle ilgili olarak öğretim programlarında dengeli bir dağılımın olmadığ 1 tespit edilmiştir. ${ }^{18,20-25}$ Buradan hareketle İSG ön lisans eğitimindeki mevcut programlar yeniden gözden geçirilerek dersler programlara yerleştirilirken derslerin birbiri ile ve diğer derslerle ilişkisine ve zorunlu-seçmeli durumlarına dikkat edilmesi gerekmektedir. 
Mevcut sistemde derslerin kredilendirilmesi konusunda iki uygulama bulunmaktadır. Bunlardan birincisi ulusal kredi sistemi, diğeri ise AKTS'dir. Araştırma, verilen derslerin ulusal ve AKTS kredileri açısından değerlendirildiğinde, üniversitelerin verdikleri ulusal kredileri aynı değerde olmasına rağmen AKTS değerlerinin ulusal kredilerinden daha çok olduğu tespit edilmiştir. Aynı derslerin farklı üniversitelerde farklı AKTS ile değerlendirilmesi de göze çarpmaktadır. Kredi dağılımının neye göre yapıldığ belli değildir. Bir üniversitede bir derse 2 AKTS verilirken aynı ders için başka üniversitelerde 3-12 arasında değişen AKTS verildiği saptanmıştır. $\mathrm{Bu}$ durum, iki öğrencinin yaptığ 1 çalışmada önemli bir farklılık olmasını gerektirir. 2-12 AKTS arasında önemli bir iş yükü vardır. $\mathrm{Bu}$ derste uygulama, proje gibi etkinlik ögelerine yer verilmesi gerekmektedir. Bazı derslerin uygulama saatinin olmadiğı ve bu derslerin iki teorik ders saati olarak tanımlandığ 1 için AKTS hesaplamalarının gerçekçi yapılmadığı söylenebilir. Literatürde bu araştırmanın sonuçlarıyla paralel şekilde, derslerin AKTS kredilerinin farklilıklar gösterdiği sonucuna ulaşan çalışmalar bulunmaktadır. Kardaş (2020) tarafından yapılan çalışmada AKTS kredi puanlarının bölümlere göre değişiklikler gösterdiği saptanmıştır. $^{20}$ Duman (2019) tarafindan yapılan çalışmada ise akademisyenler, programda yer alan derslerin AKTS hesaplamasının gerçek ders sürecine dayalı olarak yapılmadığını belirtmişlerdir. Ayrıca bilgi paketleri içinde yer alan sınıf diş1 çalışma süresi, sınava çalışma süresi, ödev, sunum gibi pek çok etkinliğe ayrılan sürelerin gerçek süreler olmadığ 1 , bu sürelere dayalı olarak ortaya çıkan AKTS saatinin de dersi yansıtmadığ 1 tespit edilmiştir. Bunun yanında akademisyenlerin bazıları derslerin bilgi paketlerine ve AKTS tablolarına dikkat ederek ders planlaması yaptıklarını belirtirken, akademisyenlerin büyük bir kısmı derslerine ilişkin Bologna bilgi paketlerini incelemediklerini ve derslerini AKTS tablolarına göre sürdürmediklerini ifade etmiştir. $^{26}$
$\mathrm{Bu}$ kadar farklılık gösteren bir yapıya bakıldığında, Türkiye'de YÖK tarafından kapsayıcı bir yönetmeliği dahi bulunmayan MYO'ların, bu yapının içerisinde ortak paydaşlar olarak belirlenen hedefleri gerçekleştirmesinin çok zor olacağ öngörülse de, mesleki ve teknik eğitim niteliğinin Bologna Süreci'yle gerçekleştirilmek istenen hedefler doğrultusunda sistematik bir değișime/gelişime uğraması kaçınılmaz olacaktır. ${ }^{27}$ Ülkelerin yükseköğretim alanında yaşadığı sorunların çözümüne yönelik olarak oluşturdukları organizasyonlardan birisi olan Bologna Süreci, böyle bir yapılanmayı gerçekleştirmek amacıyla Türkiye mesleki ve teknik eğitim yapısının geliştirilmesinde önemli bir rol oynayabilir. Süreç, öncelikli olarak mevcut program yapısını düzenleyerek ön lisans düzeyinde eğitim veren bütün program alanlarında; program yeterlilikleri, dersin amac1, dersin hedefi, dersin AKTS kredisi, dersin içeriği, dersin öğretim yöntem-teknik ve stratejisi, ders ögrenme kazanımları gibi uluslararası kalite güvence sistemleriyle desteklenmiş, öğrenci merkezli modern bir öğretim yeniliğini ifade etmektedir. ${ }^{28} \mathrm{AB}$ 'de ortak bir yükseköğretim sistemine geçmek amaciyla oluşturulan Bologna Süreci, Türkiye'deki yükseköğretim sistemini de etkilemiştir. AB tarafından 2006 yılında Türkiye için hazırlanan ilerleme raporunda YÖK Genel Kurulu'nun 11 Mart 2005 tarihli toplantısında almış olduğu karar ile Türkiye'deki bütün yükseköğretim kurumlarında 2005-2006 Eğitim Öğretim Y11 sonundan itibaren zorunlu bir uygulama haline getirilen AKTS, Bologna Süreci'nin yükseköğretimde uygulanması açısından önemli bir gelişme olarak nitelendirilmektedir. ${ }^{29,30}$

Türkiye'deki İSG ön lisans programlarının Bologna Süreci kapsamında seçmeli ders oranlarının dağılımı bakımından bir dönüşümün gerçekleşip gerçekleşmediğini tespit edebilmek için ders programları incelenmiştir. $\mathrm{Bu}$ süreçte bir ön lisans öğrencisinin mezun olabilmesi için dört dönem sonunda en az 120 AKTS almış olması gerekmektedir. $\mathrm{Bu}$ araştırmada, Türkiye'deki İSG ön lisans programlarının 
\%96,15'inde 120 AKTS kriterine uyulduğu tespit edilmiştir. Türten Kaymaz vd. (2017) hemşirelik lisans programları üzerine yapmış oldukları çalışmada programların \%81'inin 240 AKTS'yi kapsadığını tespit etmiştir. ${ }^{21}$ Dalkılıç (2015) ise sağlık kurumları işletmeciliği lisans programlarını incelediği çalışmasında üniversitelerin standartlara uygun olarak toplam 240 AKTS kredisine sahip olduğunu saptamıştır. ${ }^{24}$

Toplumun refahı için her yönüyle kendilerini geliştirmiş nitelikli bireylere ihtiyaç vardır. Yaşamış olduğu topluma ayak uydurabilen ve yeteneklerini kullanabilen bireyler yetiştirmek eğitimin en önemli amaçlarından biridir. Bunun için bireylerin çok yönlü eğitimine ve gelişimine önem verilmelidir. $^{31}$ Toplumsal ve küresel gelişmeler, eğitimde bireylerin sadece akademik yönden değil sosyal ve bireysel yönden de gelişimini desteklemesi gerektiğini ortaya koymuştur. $\mathrm{Bu}$ nedenlerden dolayı bireysel farklılıklara önem veren, öğrencinin ilgi ve yeteneklerini destekleyip ihtiyaçlarını karşılayan, öğrenciyi eğitimin merkezine alan, kendi içinde çeşitliliğe giden esnek öğretim programlarının uygulanmasının zorunluluğu gündeme gelmiştir. $\mathrm{Bu}$ yüzden, öğretim programındaki zorunlu derslerin yanı sira seçmeli derslere yer verilmesini ve her ögrenci grubu için farklı programların uygulanmasını gerekli kılmıştır. ${ }^{32}$ Bologna Süreci'nin ders programları açısından getirdiği önemli düzenlemelerden biri de seçmeli derslerin her eğitim öğretim döneminde belli kredi oranında verilmesidir. Bologna Süreci'ne dahil olan üniversitelerin oluşturdukları programlarındaki derslerin en az \%25'inin (30 AKTS) seçmeli olması gerekmektedir. ${ }^{28}$

Araştırma, seçmeli ders kriteri açısından değerlendirildiğinde, seçmeli ders kriteri olan $\% 25$ (30 AKTS) uygulamasının yeterli düzeyde olmadığı tespit edilmiştir. İSG ön lisans programlarının \%32.05'inin (25) Bologna Süreci'nde istenen \%25 seçmeli ders kriterini yerine getirdiği, 53 programın ise istenilen kriterin altında olduğu belirlenmiştir. Ayrıca 8 programda hiçbir seçmeli dersin olmadığı, 18 programın ise seçmeli ders oranının \%10'un altında olduğu saptanmıştır (Tablo 2). Konu ile ilgili yapılan çalışmalardan, Terzi vd. (2013) Türkiye'deki işletme bölümlerinin ders programlarını Bologna Süreci kapsamında inceledikleri çalışmada, muhasebe ile ilgili verilen zorunlu derslerin ortalama AKTS'lerinin devlet üniversitelerinde $194 \quad$ olduğunu belirlemişlerdir. Bundan dolayı bazı devlet üniversitelerinin Bologna Süreci'nde istenen $\% 25$ seçmeli ders kriterini yerine getirmediğini saptamışlardır. ${ }^{33}$ Benzer şekilde Sağlam vd. (2015) Bologna Süreci kapsamında Türkiye'deki fizyoterapi ve rehabilitasyon bölümlerinin ders kataloglarını inceledikleri çalışmada vakıf üniversitelerinin $\% \quad 62$ 'sinin, devlet üniversitelerinin ise \%56'sının seçmeli ders kriterini sağlamadığını tespit etmişlerdir. ${ }^{23}$ Ayrıca Kavak vd. (2015) hukuk fakültelerini inceledikleri çalıșmada üç üniversitenin Bologna Süreci'nde istenen \%25 seçmeli ders kriterini yerine getirdiğini, iki üniversitenin ise istenen kriterin altında kaldığını belirlemişlerdir. ${ }^{23}$ Türten Kaymaz vd. (2017) tarafindan yapılan diğer bir program analizi çalışmasında da üniversitelerin \%59'unda seçmeli ders kriterine uyulmadığ 1 tespit edilmiştir. ${ }^{21}$ ISG ön lisans programlarını incelediğimiz bu araştırma ve yapılan diğer çalışmalarda öğrencilerin ilgi ve ihtiyaçları doğrultusunda seçmeli ders açılmasında bazı sorunların yaşandığı ve Bologna Süreci'nde istenen seçmeli ders kriterine uyulmadığ söylenebilir.

Araştırma, uygulama dersleri açısından değerlendirildiğinde, bazı üniversitelerde staj uygulamasının olmadığı, bazılarında ise tamamen öğrencinin isteğine birakıldığ1 belirlenmiştir. Öğrencilerin istihdama yönelik yetişmelerini sağlamak amacı ile bazı programlarda eğitim öğretimin 3 döneminin okulda teorik ders olarak, 1 döneminin ise işletmelerde uygulama olarak yapıldığ 1 tespit edilmiştir. Ayrıca bazı programlarda öğrencilerin eğitim sürecinde öğrendikleri bilgi ve deneyimlerini "Mesleki Uygulamalar", "İşyerinde Uygulama", "Staj" vb. dersler kapsamında pekiştirme imkânı 
bulduğu tespit edilmiştir. $\mathrm{Bu}$ açıdan araştırma yapılan İSG ön lisans programlarının \%57,69'unda (45) bu tür derslere programlarında yer verildiği belirlenmiştir. Terzi vd. tarafından yapılan çalışmada ise üniversitelerin ortalama olarak proje/saha çalışmaları gibi derslere $\% 1$ oranında yer verildiği saptanmıştır. ${ }^{33}$ Kardaş (2020) yaptığı çalışmada ders programlarında mesleğin pratiğine yönelik derslerin az olduğunu ve hem teorik hem de uygulama saatlerinde farklılıkların olduğunu tespit etmiştir. ${ }^{20}$ Uygulamalı verilen derslerin kalıcılığı, teorik düzeyde verilen eğitimlere göre daha fazladir. Buradan hareketle öğrencilere verilen eğitimin daha fazla anlaşılırlığını sağlamak ve kalitesini arttırmak amaciyla Bologna Süreci kapsamında daha fazla proje ve saha çalışmalarına önemli verilmelidir.

Araştırma, ders içerikleri açısından değerlendirildiğinde, içeriği aynı fakat ismi farklı olan dersler, içerik ve ismen ortak dersler ve bir dersin içeriğinin birden fazla ders içeriğinde bulunduğu tespit edilmiştir. $\mathrm{Bu}$ sonuçlardan hareketle derslerin içeriklerinin birbiriyle örtüşmediği ve bir dönemde 14 hafta boyunca incelenen bir ders diğer bir üniversitede başka bir ders adı altında 3-4 haftada incelendiği söylenebilir. Literatürde bu araştırmanın sonuçlarıyla paralel şekilde Kaplanvural (2018), 16 vakıf üniversitesinin İSG ön lisans programlarını incelediği çalışmasında ders içeriklerinin birbiriyle örtüşmediğini saptamıştır. ${ }^{34}$

ISG ön lisans programlar1 değerlendirildiğinde, standart bir uygulama bulunmadığ 1 tespit edilmiştir. Programların genel amac1, ISG teknikeri yetiştirmektir. Programların amaçları aynı olmasına rağmen, uygulanan ders programlarındaki farklılıklar dikkat çekmektedir. Bazı derslerin üniversitelerde aynı dönemde okutulmadığı, zorunlu-seçmeli ile teorik-uygulama ders oranlarının birbirinden farklı olduğu, ulusal kredi ve AKTS'lerin üniversiteden üniversiteye göre farklılık gösterdiği tespit edilmiştir. Literatürde yer alan araştırmalar bu sonuçlarla benzerli taşımaktadır. Erdurak (2016) tarafından yapılan çalışmada da farklı ders adları, farklı krediler ve farklı dönemlerde okutulan derslerle karşılaşılmıştır. ${ }^{25}$ Buradan hareketle üniversitelerde bulunan her İSG ön lisans programı kendi öğretim programını oluşturduğu söylenebilir. İSG programlarında yer alan derslerin süresi, derslere verilen ulusal ve AKTS kredisi, dersin verildiği dönem, öğretim programı içeriğinde yer alan konulardaki eksiklik ve tutarsızlıklar, öğrencilerin yatay ve dikey geçiş aşamalarında yaşadıkları sıkıntılar sorun olarak karşımıza çıkmaktadır.

İSG ön lisans eğitimi ile ilgili program belirleme çalışmalarının üniversitelere bırakılması, İSG eğitiminin zenginleşmesi anlamında çeşitlenmesine değil dağınıklığına, karmaşıklığına yol açmıştır. $\mathrm{Bu}$ araştırma ile benzerlik gösteren Erdurak (2016), Türkiye'de sosyal hizmet bölümlerini analiz ettiği çalışmasında, derslerin gerek ulusal gerekse AKTS ders kredileri, okutuldukları dönemler, zorunlu-seçmeli durumları ve teorik-uygulama durumlarının üniversiteden üniversiteye göre değiştiğini tespit etmiştir. ${ }^{25}$ Buradan hareketle İSG ön lisans programları arasında; ders adları, ders kredileri, derslerin seçmeli ya da zorunlu olması ve ders içerikleri gibi konularda farklılıklar göstermesinden dolayı İSG ön lisans eğitiminin standart olmayan bir zeminde devam ettiğini belirtmek mümkündür. $\mathrm{Bu}$ durumda yeni açılan İSG ön lisans programlarının ders planları hazırlanırken daha önceden kurulmuş olan programların ders planları üzerinden değişiklik yaparak akademisyen kadrosuna göre programların şekillendirildiği söylenebilir. Ayrıca ders programlarının birbirinden farklı olmas1, farklı mesleki yeterlilikte mezunların ortaya çıkmasına neden olduğu söylenebilir. Bu bağlamda İSG eğitimindeki mevcut programlar gözden geçirilerek mesleki yeterliliklerin kazanılması için uygun öğretim program modeli geliştirilmelidir. 


\section{SONUÇ VE ÖNERILER}

Türkiye'deki 84 üniversitede ön lisans düzeyinde İSG eğitimi veren 145 program tespit edilmiştir. 2012 yılında açılan İSG ön lisans program sayıs1 36, 2015 yilında 93, 2018 y1lında 137 iken, bu say1 2019 y1lında 145 olmuştur. İS ön lisans programlarındaki bu hızlı artış bazı sıkıntıları da beraberinde getirmiştir. Her üniversite akademisyen profiline göre kendi ders programlarını, ders kredilerini ve ders içeriklerini oluşturmuş, bu durum da ISG eğitiminde belli bir standarda değil çeşitliliğe yol açmıştır.

ISG teknikeri yetiştirmek amacıyla hazırlanan İSG ön lisans programlarının amaçları aynı olsa da uygulanan ders programlarındaki farklılıklar göze çarpmıştır. Üniversitelerin gerek şekil gerekse derslerin kredi ve içerikleri konusunda aralarında önemli farklılıklar olduğu tespit edilmiştir. ISG eğitimi ile ilgili program düzenlemelerinin tamamen üniversitelere bırakılması, ISSG eğitiminin zenginleşmesi anlamında çeşitlenmesine değil dağınıklığa ve karmaşıklığa yol açtığı görülmüştür. Ayrıca Avrupa'da ortak bir yükseköğrenim alanı oluşturmak amaciyla yapılan anlaşmalardan biri olan Bologna Süreci'ne katılan Türkiye'nin İSG ön lisans programlarında Bologna kriterleri açısından da bazı sorunların olduğu tespit edilmiştir. İSG ön lisans programlarının \%67,95'inin
Bologna Süreci'nde istenen ders kredilerinin en az \%25'inin (30 AKTS) seçmeli ders kredisi olma kriterinin altında olduğu belirlenmiştir.

İSG ön lisans programları değerlendirildiğinde standart bir uygulama bulunmadığı saptanmıştır. Araştırmada farklı ders adları, farklı krediler ve farklı dönemlerde okutulan derslerle karşılaşılmıştır. Programlar arası bir birliktelik değil dağınıklık ve kopukluk olduğu tespit edilmiştir. Programların açılışında birbirlerinden yararlanmaktan kaynaklı içerik ve uygulama yönüyle ortak olan programlar mevcut olsa da; derslerin içerikleri, kredi-AKTS ve uygulama ile teorik derslerin oranları yönleriyle programlar arasında tam bir uzlaşmanın olmadığı görülmüştür.

Program analizi sonucunda, ISG eğitiminde bir standart olması gerekliliği ortaya çıkmıştır. Türkiye'de ISG eğitimi veren MYO'ların programlarındaki derslerin isimleri, içerikleri ve kredileri uyumlu hale getirilerek İSG ön lisans eğitiminde bir standart oluşturulmalı ve programların kendi amacina uygun ders içerikleri hazırlanmalıdır. İSG ön lisans eğitiminde standart oluşturulurken günün koşulları, sektör beklentileri ve teknolojideki gelişmeler göz önünde bulundurulmalıdır. 


\section{KAYNAKLAR}

1. Gerek, N. (2008). İşçi Sağlığı ve İş Güvenliği. Eskişehir: Anadolu Üniversitesi AÖF Yayını.

2. Coşkun, B. (2007). Türkiye'de İşçi ve İşverenlerin İş Sağlığ ve Güvenliği Açısında Görev ve Sorumlulukları. (Yüksek Lisans Tezi), Beykent Üniversitesi Sosyal Bilimler Enstitüsü, İstanbul.

3. Yılmaz, F. (2009). Avrupa Birliği ve Türkiye'de İş Sağlığı ve Güvenliği: Türkiye'de İş Sağlığı ve Güvenliği Kurullarının Etkinlik Düzeyinin Ölçülmesi. (Doktora Tezi), İstanbul Üniversitesi Sosyal Bilimler Enstitüsü, İstanbul.

4. İşçi Sağlığ 1 ve İș Güvenliği Raporu (2015). Erișim adresi https://mmo.org.tr/sites/default/files/gonderi_dosya_ekleri/c8 19fd7f01dd438_ek_0.pdf (Erişim tarihi:15.2.2020).

5. Ulutaşdemir, N. ve Tuna, H. (2019). “Analysis of Occupational Health and Safety Programs in Associate, Undergraduate and Graduate Degree (The Sample of Turkey's Seven Regions)". Journal of the International Scientific Research, 4 (1), 66-80.

6. Yıldırım, E. (2010). İşçi Sağlığı ve İş Güvenliğinde Eğitimin Rolü ve İşgörenlerin İşçi Sağlığı ve İş Güvenliği Eğitimi Konusundaki Bilinç Düzeylerini Ölçmeye Yönelik Bir Araștırma. (Yüksek Lisans Tezi), İstanbul Üniversitesi Sosyal Bilimler Enstitüsü, İstanbul.

7. Bilir, N. (2016). İş Sağlığı ve Güvenliği Profili Türkiye Erişim adresi: https://www.ailevecalisma.gov.tr/ medias/4578/kitap09.pdf (Erişim tarihi:15.02.2020).

8. Ekmekçi, Ö. (2006). "Iş Sağlığı ve Güvenliği Eğitiminin Usul ve Esasları". Mercek Dergisi, 41, 100-107.

9. İş Sağlığı ve Güvenliği Kanunu. (2012). 28339, Tarih: $30 / 06 / 2012$

10. İș Güvenliği Uzmanlarının Görev, Yetki, Sorumluluk ve Eğitimleri Hakkında Yönetmelik. (2012). 28512, 29/12/2012.

11. Ceylan, H. (2012). “Türkiye'deki İș Sağlığı ve Güvenliği Eğitimi Sorunlar ve Çözüm Önerileri”. Electronic Journal of Vocational Colleges, 22, 94-104.

12. Arıkan, R. ve Sarı, Y.D. (2017). Milli Eğitimde İş Sağlığı ve Güvenliğinin Önemi. Erisim adresi: https://docplayer.biz.tr/3356635-Milli-egitimde-is-sagligi-veguvenliginin-onemi-rafet-arikan-yasin-dursun-sari-atilimuniversitesi-muhendislik-fakultesi-incek-ankara.html (Erișim tarihi: 15.02 .2020$)$

13. Sivrikaya, O. (2016). “Türkiye'de Yükseköğretim Kurumlarında İş Sağlığı ve Güvenliği Eğitiminde Güncel Durum”. Yükseköğretim ve Bilim Dergisi, 6 (2), 151-162.

14. Öğrenci Seçme ve Yerleştirme Merkezi (2018) Yükseköğretim Programları ve Kontenjanları Kılavuzu. Erişim adresi: https://www.osym.gov.tr/TR,15240/2018 yuksekogretim-programlari-ve-kontenjanlari-kilavuzu.html (Erişim tarihi: 02.01.2019)

15. YÖK İstatistik (2020). https://istatistik.yok.gov.tr/ (Erişim tarihi: 12.01.2020)

16. Çiçek, H, Demirel, M. ve Onat, O.K. (2010). "İşletmelerin Web Sitelerinin Değerlendirilmesine İliskin Bir Arastırma: Burdur İli Örneği”. Süleyman Demirel Üniversitesi İktisadi ve İdari Bilimler Fakültesi Dergisi, 15 (2), 187-206.

17. Zaif, F. ve Ayanoğlu, Y. (2007). "Muhasebe Eğitiminde Kalitenin Arttırılmasında Ders Programlarının Önemi: Türkiye’de Bir İnceleme”. Gazi Üniversitesi İktisadi ve İdari Bilimler Fakültesi Dergisi, 9 (1), 115-136.
18. Sezen, T.S. (2018). Gastronomi Eğitiminin Mevcut Durumunun Analizine Yönelik Bir Araștırma. (Yüksek Lisans Tezi), Balıkesir Üniversitesi Sosyal Bilimler Enstitüsü, Balıkesir.

19. Görkem, H. (2013). Türkiye Üniversiteleri Maliye Bölümlerinin Bologna Süreci Çerçevesinde Değerlendirilmesi. (Doktora Tezi), Marmara Üniversitesi Sosyal Bilimler Enstitüsü, İstanbul.

20. Kardaş, K. (2020). Turizm Rehberliği Bölümleri İçin Araştırma ve Müfredat Kapsam Önerisi. (Yüksek Lisans Tezi), Mersin Üniversitesi Sosyal Bilimler Enstitüsü, Mersin.

21. Türten Kaymaz, T, Şimşek Çetinkaya, Ş, Bakır, E, Üzar Özçetin, Y.S, Gül, S, Ercan Şahin, N, Uslu Şahan, F, Başaran S. ve Tunçbilek, Z. (2017). "Türkiye'deki Hemşirelik Lisans Programlarının Web Sayfalarında Bologna Sürecinin Yansimaları". Journal of Higher Education and Science, 7 (1), 91-97.

22. Sağlam, M, Vardar Yağlı, N, Çakmak, A, Avcu, F, Turgut, E Harput, G, Güney, H, Ateş Numanoğlu, E, Gür, G, Kara, Ö, Ülger, Ö, Aksu Yıldırım, S. ve Karaduman, A. (2015). "Bologna Sürecine Dayalı Örnek İnceleme: Fizyoterapi ve Rehabilitasyon Bölümlerinde Seçmeli Ders Oranı”. 17-18 Eylül 2015 I. Bologna Süreci Araştırmaları Kongresi (103107), Ankara

23. Kavak, Y, Seferoğlu, S.S, Atalay Kabasakal, K, Sen, Z. ve Uludağ, G. (2015). "Eğitim Alanındaki Değişimler ve Hukuk Öğretimi: Bologna Süreci'ne Dayalı Örnek İnceleme”. Journal of Higher Education and Science, 5 (1), 1-13.

24. Dalkılıç, S. (2015). Sağlık Kurumları İşletmeciliği Lisans Programlarının Müfredatlarının İncelenmesi. (Yüksek Lisans Tezi), Başkent Üniversitesi Sosyal Bilimler Enstitüsü, Ankara.

25. Erdurak, Y. (2016). Türkiye'de Sosyal Hizmet Bölümler Müfredat Programlarının Analizi. (Yüksek Lisans Tezi), Yalova Üniversitesi Sosyal Bilimler Enstitüsü, Yalova.

26. Duman, S.N. (2019). Hizmet Öncesi Öğretmen Eğitiminde Öğretmenlik Meslek Bilgisi Derslerinin Değerlendirilmesi. (Doktora Tezi), Gazi Üniversitesi Eğitim Bilimleri Enstitüsü, Ankara.

27. Turkaya, A. (2013). Ülkemizde Sektörel Gereksinimler Ekseninde Meslek Yüksekokulları Grafik Tasarımı Programları. (Yüksek Lisans Tezi), Ondokuzmayıs Üniversitesi Eğitim Bilimleri Enstitüsü, Samsun.

28. Yükseköğretim Kurulu. (2010). Yükseköğretimde Yeniden Yapılanma: 66 Soruda Bologna Süreci Uygulamaları. Erisim adresi:https://uluslararasi.yok.gov.tr/Documents/yay\%C4\%B 1nlar/yuksekogretimde_yeniden_yapilanma_66_soruda_bolo gna_2010.pdf (Erişim tarihi: 12.03.2020).

29. Eurydice (2010). Türk eğitim sisteminin örgütlenmesi 2008/09. Erișim adresi: http://eacea.ec.europa.eu/education/ eurydice/documents/eurybase/eurybase_full_reports/TR_TR. pdf (Erişim tarihi: 05.07.2020).

30. Gülcan, M.G. (2010). Avrupa Birliği ve Eğitim. Ankara: Pegem Akademi.

31. Eğitimi Araştırma ve Geliştirme Dairesi Başkanlığı. (2008) Seçmeli Derslerin Seçim Kriterlerinin Değerlendirilmesi Araştırması. Ankara

32. Kuzgun, K, Sevim, S.A, Ersever, H, Akbalık, G, Pișkin, M ve Hamamc1, Z. (1997). "Öğrencilerin Akademik Danıșmanlarından Bekledikleri Görevler ve Danıssmanların Görev Algıları". Ankara Üniversitesi Eğitim Bilimleri Fakültesi Dergisi, 30 (1), 27-43. 
33. Terzi, S, Kiymetli Şen, İ. ve Solak, B. (2013). "Bologna Sürecinin Muhasebe Eğitimine Etkisi: Üniversitelerin İșletme Bölümlerinin Ders Programları Üzerine Bir İnceleme". Muhasebe ve Finansman Dergisi, 83-99.

34. Kaplanvural, S. (2018). Sağlı Hizmetleri Meslek Yüksekokulu İş Sağlığı ve Güvenliği Programı İçin Eski ve Yeni Müfredatın Karșılastırılması (Bir Vakıf Üniversitesi Örneği). (Yüksek Lisans Tezi), Üsküdar Üniversitesi Sağlık Bilimleri Enstitüsü, İstanbul. 